\title{
The association between increased maternal PARK7 (DJ-1) levels and the occurrence of preterm premature rupture of membranes - A randomized prospective study
}

\author{
Artmış maternal parkinson hastalı̆̆ proteini 7 düzeyinin \\ preterm prematür membran rüptürü ile ilişkisi - Prospektif \\ randomize bir çalışma
}

\author{
(D) Uğur Turhan'1, (D) Burak Tatar² \\ 1University of Health Sciences Turkey, Samsun Training and Research Hospital, Clinic of Obstetrics and Gynecology, Division of Perinatology, Samsun, \\ Turkey \\ 2University of Health Sciences Turkey, Samsun Training and Research Hospital, Clinic of Obstetrics and Gynecology, Division of Gynecological Oncology, \\ Samsun, Turkey
}

\begin{abstract}
Objective: Parkinson's disease protein 7 (PARK7/DJ-1) is an important antioxidant multiprotein against inflammation and oxidative stress. We therefore planned this study to demonstrate the association between maternal PARK7 levels and the occurrence of preterm premature rupture of membranes (PPROM).

Materials and Methods: We enrolled 80 pregnant women; 50 PPROM patients and 30 healthy controls, into this cross- sectional study between the $24^{\text {th }}$ and $36^{\text {th }}$ gestational weeks. Furthermore, we measured serum PARK 7 levels using enzyme-Linked immunosorbent assay method.

Results: Plasma PARK7 levels were higher in PPROM patients compared to those in the healthy controls ( $\mathrm{p}<0.001$ ). With a cutoff value of $2.57 \mathrm{pg} / \mathrm{mL}$; PARK 7 had a $92 \%$ sensitivity, $86 \%$ specificity, $88 \%$ positive predictive value and $83 \%$ negative predictive value ( $<<0.01$ ) for PPROM. PARK7 had positive correlation with blood leukocyte levels $(\mathrm{p}<0.001)$, C-reactive protein levels $(\mathrm{p}<0.001)$, and negatively correlated with birth weight and birth week.

Conclusion: PARK 7 is overexpressed in PPROM patients. Due to its anti-inflammatory and antioxidant properties, PARK7 may be a novel marker in better understanding the pathophysiology and prediction of the prognosis PPROM. Further large-scale studies are needed.
\end{abstract}

Keywords: Preterm premature rupture of membranes (PPROM), oxidative stress, inflammation, Parkinson's disease protein 7 (PARK7), DJ-1

Öz

Amaç: Parkinson hastalığı protein 7 (PARK7) enflamasyon ve oksidatif strese karşı önemli bir antioksidan multiproteindir. Bu çalışmayı preterm prematüre membran rüptürü (PPROM) hastalarında maternal PARK (DJ-1) düzeyini araştırmak için tasarladık

Gereç ve Yöntemler: Kesitsel çalışmaya 24-36. gebelik haftaları arasında 50 PPROM ve 30 sağlıklı kontrol hastası olmak üzere toplamda 80 hasta dahil edildi. Enzim-Bağlı immünosorbent tahlili yöntemiyle maternal serum PARK 7 seviyeleri ölçüldü.

Bulgular: PPROM hastalarında sağlıklı kontrollere göre plazma PARK7 düzeyleri daha yüksekti ( $\mathrm{p}<0,001)$. PARK7, kanda lökosit düzeyleri (p<0,001), CRP düzeyleri $(\mathrm{p}<0,001)$ ile pozitif, doğum ağırlığı ve doğum haftası ile negatif korelasyon gösterdi.

Sonuç: PARK 7, PPROM hastalarında aşırı eksprese edilmektedir. Anti-enflamatuvar ve antioksidan özelliklerinden dolayı PARK7, PPROM patofizyolojisini ve prognozunu öngörmede yeni bir belirteç olabilir. Daha geniş çalışmalara ihtiyaç vardır.

Anahtar Kelimeler: Preterm prematür membran rüptürü (PPROM), oksidatif stres, enflamasyon, Parkinson hastalığı protein 7 (PARK 7), DJ-1

PRECIS: Maternal serum PARK7 levels are elevated in PPROM patients. PARK 7 levels can be combined with WBC, CRP, PCT in PPROM followup.


Perinatology, Samsun, Turkey

Phone: +90 5058954000 E-mail: drugurturhan@hotmail.com ORCID ID: orcid.org/0000-0002-0653-0630

Received/Geliș Tarihi: 23.08.2021 Accepted/Kabul Tarihi: 12.11.2021

${ }^{\circledR}$ Copyright 2021 by Turkish Society of Obstetrics and Gynecology

Turkish Journal of Obstetrics and Gynecology published by Galenos Publishing House. 


\section{Introduction}

As the cause of approximately one-third of preterm births, preterm premature rupture of membranes (PPROM), has an incidence of 3\% of all pregnancies. PPROM is defined as the rupture of the amniotic membrane which leads to leakage of amniotic fluid before 37 weeks of gestation ${ }^{(1)}$. Although risk factors like history of PPROM in previous pregnancies, second or third trimester vaginal bleeding, vitamin deficiency, connective tissue diseases, smoking, alcohol use, low body mass index (BMI), diabetes mellitus are known, the etiopathology is not fully understood. Besides, PPROM cannot be predicted ${ }^{(2-4)}$. The complications associated with PPROM include chorioamnionitis (CA), oligohydramnios, prematurity, and intrauterine death ${ }^{(5,6)}$. Among the predisposing factors, the most potential risk factor is infection and inflammation. Infection leads to releasing of proinflammatory cytokines from amniotic membrane and decidua $^{(7)}$. Infection is seen with a frequency of $15 \%-25 \%$ in the antepartum period and 15\%-20\% in the postpartum period in PPROM patients ${ }^{(8)}$. The aim of the follow-up period is to monitor closely the clinical signs of infection and then deciding the time of active labor with close monitoring of signs of CA until reaching the $34^{\text {th }}$ week of gestation, if possible.

Currently, there are no accepted diagnostic markers predicting the risk of CA. White blood cell count (WBC), C-reactive protein (CRP), Procalcitonin (PCT), interleukin-6 (IL-6), fasting blood glucose and heat-shock proteins are the most studied markers ${ }^{(9-11)}$. WBC increases physiologically during gestation and is increased further with exogenous antenatal steroids administered. Thus, its value in CA clinical diagnosis is limited. CRP, another marker increased physiologically during pregnancy, has limited value in the clinical practice of CA because it increases in the late period of the infection. PCT is an acute phase reactant that shows monocyte activity and does not increase in normal pregnancy. Many studies are inconsistent with its predictive power for $\mathrm{CA}^{(12-14)}$.

PARK 7, also known as Parkinson's disease protein 7 (PARK7/ DJ-1), has the gene on the short arm of chromosome 1 (1p36.12- 1p36.33), and was first identified with Parkinson's disease ${ }^{(15,16)}$. It has been identified in more than 20 tissues including fetal membranes and placenta, and its main role is to provide cellular protection against oxidative stress ${ }^{(17)}$. In neural tissue, it is responsible for astrocyte activation during oxidative stress, regulating genes such as glutamate cysteine ligase, extracellular superoxide dismutase (SOD3) or manganese superoxide dismutase ${ }^{(18)}$.

PARK-7 expression increases especially in sepsis, in concordance with its role in impairing bacterial clearance with decreasing ROS production ${ }^{(19)}$. The increased PARK-7 binds to p47phox, a critical component of NADPH, thereby disrupting the NADPH oxidation complex. PARK-7 performs this function by facilitating Nox2 (gp91phox) ubiquitination ${ }^{(19)}$. Macrophage and concurrent cytokine stimulation from the bone marrow due to increased endotoxin levels secondary to infection increases DJ-1 mRNA and protein expression ${ }^{(20)}$

To this respect, we hypothesized that PARK-7 expression and its maternal serum levels in PPROM patients should be higher. In this pilot study, we investigated the efficacy of measuring PARK7 levels in maternal serum in subclinical infections such as PPROM without CA.

\section{Materials and Methods}

This cross-sectional study was carried out in the Samsun Training and Research Hospital between January 1, 2019 and January 1,2020 . The study was approved by the Local Ethics Committee with the approval number of CAEK 2019/2/13 in accordance with the 2003 Helsinki Declaration. We enrolled 80 pregnant women between 24 and 34 weeks gestation: 50 women with a history of PPROM were included in the study group while 30 women with healthy pregnancy course were accepted as healthy controls.

The gestational age (GA) of patients were confirmed with the last menstrual period and Crown-rump length. PPROM diagnosis was made based on the patient's history, vaginal speculum assessment and sonographic evaluation of the amniotic fluid and for indecisive cases, sampling from vaginal fluid was made with Amnisure (Qiagen, Germany).

Any chronic systemic disease (pregestational or gestational diabetes, hypertension, preeclampsia, hypohyperparathyroidism, hepatitis, asthma, cardiac pathologies and renal disease), any cervical dilatation in administration, presence of placental abnormalities (placenta previa, morbidly adherent placenta), cerclage presence in cervix, any acute infection symptoms, emergent labor indication such as nonstress test. Abnormality or abruption of placenta, and presence of fetal anomalies were excluded from the study.

After admission to inpatient clinics, urine cultures and rectovaginal Beta Streptococcus cultures were obtained from all patients. Serum Park-7 levels measured at the time of admission to the hospital, no more than 12 hours after the PPROM diagnosis. Besides, Park-7 level is measured before administration of antibiotics, steroids or magnesium sulfate. Routine prophylactic antibiotics were started (for 48 hours IV ampicillin and oral azithromycin for 6 days, and then oral ampicillin until labor) All PPROM patients received two doses of betamethasone treatment 24 hours apart for antenatal lung maturation. For fetal neuroprotection, intra-venous $4 \mathrm{~g}$ loading dose in 15 minutes continued by $1 \mathrm{~g}$ /hour magnesium sulfate was given for patients under 32 weeks of gestation for 24 hours. Patients were monitored closely with daily WBC, PCT and CRP for CA risk.

CA was diagnosed in the presence of at least three of the following symptoms: fever $\left(\geq 38^{\circ} \mathrm{C}\right)$, vaginal discharge, maternal tachycardia ( $>100$ beats/min), fetal tachycardia ( $>160$ beats/ min), abdominal pain, uterine tenderness, and leukocytosis ${ }^{(21)}$. Pregnancy termination was performed in patients diagnosed 
with CA and placenta was sent to pathology for histopathological confirmation of diagnosis.

Patients without inevitable labor, without a sign of CA and amniotic fluid index $\geq 5$ were followed-up until 34 week of gestation and then delivered.

\section{Biochemical Analysis}

Serum procalcitonin, CRP and WBC count were measured in the first day of admission to inpatient clinics. WBC level was determined with the Sysmex XP-300(®) kit. Hematology Analyzer (Sysmex, America, Inc.) CRP was measured using the immunoturbidimetric assay. Pars Azmin, Tehran, Iran) Procalcitonin value was measured with BRAHMS PCT kit (Roche Diagnostic, Mannheim, Germany). A serum level equal to or greater than $2 \mathrm{ng} / \mathrm{mL}$ was considered positive for $\mathrm{CA}^{(7)}$. We collected $5 \mathrm{~cm}^{3}$ of maternal serum after 12 hours of fasting on the first day of hospitalization in a biochemistry tube. Then, we centrifuged it at $1000 \mathrm{rpm}$ and $2{ }^{\circ} \mathrm{C}-8{ }^{\circ} \mathrm{C}$ temperature for 15 minutes. The supernatant of the serum was placed in $1.5 \mathrm{~mL}$ Eppendorf tubes and stored at $-80^{\circ} \mathrm{C}$. Maternal serum plasma PARK 7 level was measured using the ELISA kit, following the manufacturer's instructions (Recombinant Human PARK7/DJ-1 Protein (His Tag); catalog no: PKSH030826, Cusabio Biotech Co. Ltd. China).

\section{Statistical Analysis}

Data was analyzed using the Statistical Package for the Social Sciences version 20 (SPSS Inc). The distributions of all the continuous variables were tested using the KolmogorovSmirnov test. The variables with normal distribution were compared between two groups using an independent samples t-test, and were compared among more than two groups using ANOVA.

The results were expressed as the mean \pm standard deviation. The Mann-Whitney U test was used to analyze the nonnormally distributed variables involving two groups, while the KruskalWallis test was used to analyze variables involving more than two groups, and the results were expressed as median and interquartile range. If the values were significantly different in the Kruskal-Wallis test and ANOVA, then, the Bonferroni- adjusted Mann-Whitney U and Tukey-Kramer Post-hoc tests were performed, respectively.

The chi-squared test was used to compare the categorical variables, and data obtained were presented as proportions. The correlations were assessed using Spearman's correlation coefficient, along with their related p-values. A two-tailed p-value of less than 0.05 was considered statistically significant.

\section{Results}

The demographics and laboratory results of the patients are demonstrated in Table 1. There was no difference in maternal age, BMI, and GA between the PPROM and control groups. WBC accounts, serum CRP levels, and serum PARK 7 levels were significantly higher in the study group $(\mathrm{p}<0.01)$ (Figure 1).

GA at birth, birth weight and Apgar scores were significantly lower in the PPROM group (Table 2).

With a cutoff value of $2.57 \mathrm{pg} / \mathrm{mL}$; PARK 7 had $92 \%$ sensitivity. $86 \%$ specificity, $88 \%$ positive predictive value and $83 \%$ negative predictive value $(\mathrm{p}<0.01)$ for PPROM. Receiver operating characteristic curve of PARK 7 for prediction of PPROM is demonstrated in Figure 2.

PARK 7 negatively correlated with GA at birth, birth weight, $10^{\text {th }}$ minute Apgar scores $(\mathrm{p}<0.01)$, and positively correlated with WBC and serum CRP levels ( $p>0.05$ ) (Table 3).

\section{Discussion}

PARK 7 is overexpressed in PPROM patients and a cutoff value of $2.57 \mathrm{pg} / \mathrm{mL}$ seemed to have a high sensitivity and specificity for predicting PPROM. Due to its anti-inflammatory and antioxidant properties, PARK7 could be considered a novel marker in better understanding the pathophysiology and prediction of the prognosis of PPROM.

PARK 7, denominated after the discovery of familial Parkinson's disease, proves to be an important antioxidant stress regulator especially in hypoxia-induced cellular response $e^{(22)}$. It protects endothelial cells, macrophages, fibroblast cells, neurons, and pancreatic islet cells against oxidative stress in high

Table 1 . The basic characteristics and laboratory parameters

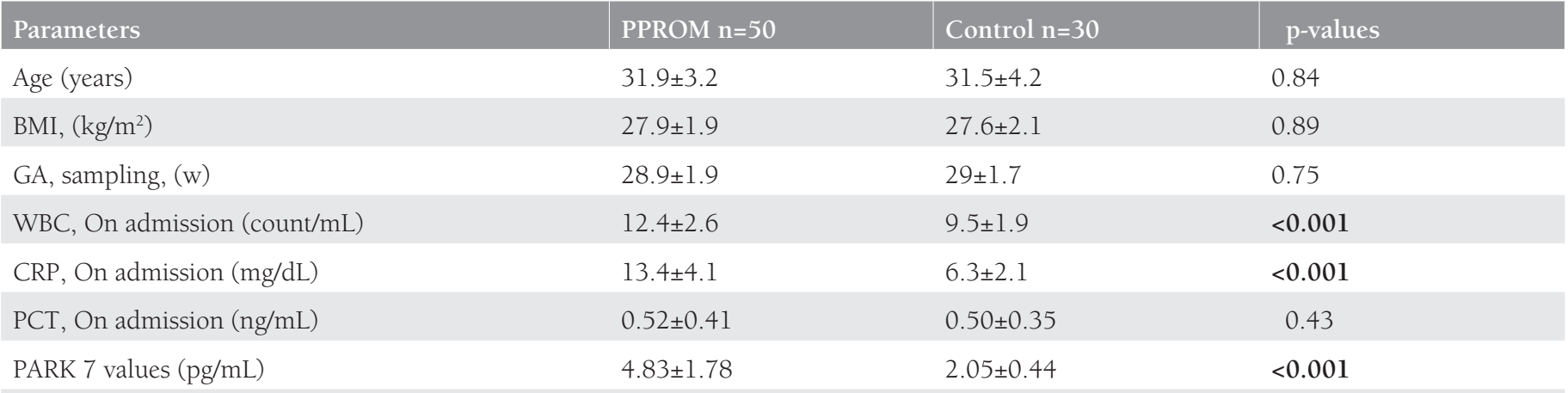

PPROM: Premature rupture of membrane, BMI: Body mass index, GA: Gestational age, W: Week, WBC: White blood cells, CRP: C-reactive protein, PCT: Procalcitonin, SD: Standard deviation Data are expressed as median (interquartile) or mean $( \pm \mathrm{SD}$ ). p-value $<0.05$ is significant 


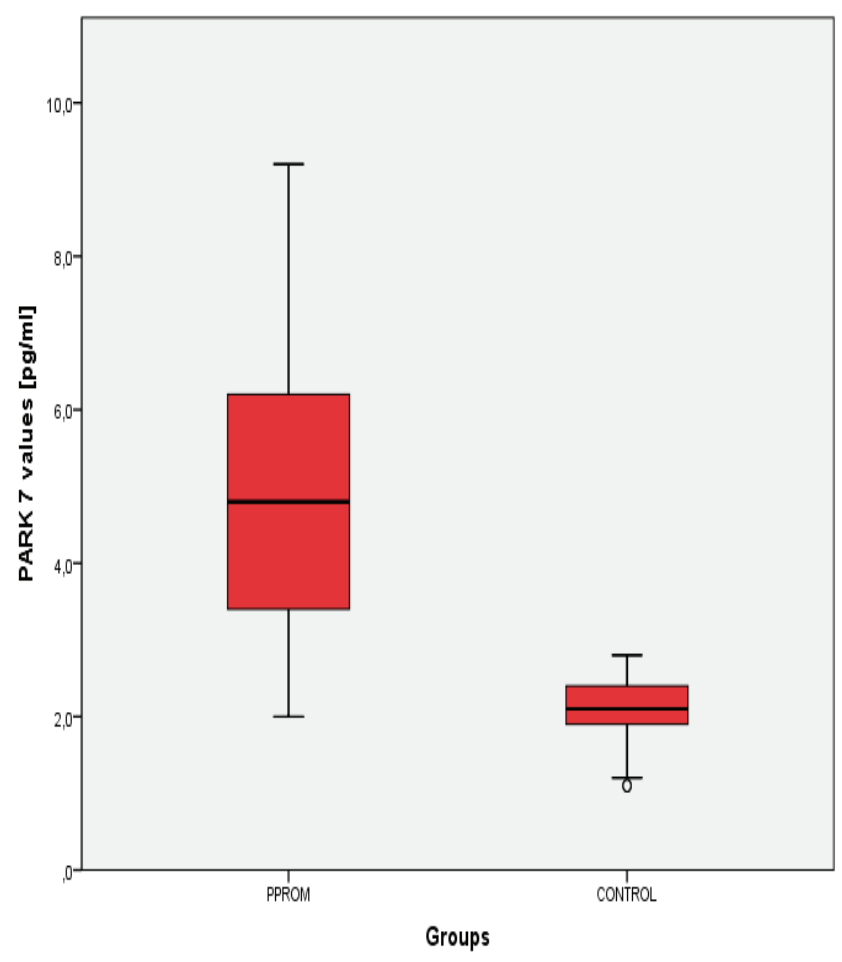

Figure 1. PARK 7 levels according to the groups

Table 2. Perinatal outcomes

\begin{tabular}{|c|c|c|c|}
\hline Outcomes & $\begin{array}{l}\text { PPROM } \\
\mathrm{n}=50\end{array}$ & $\begin{array}{l}\text { Control } \\
\mathrm{n}=30\end{array}$ & p-values \\
\hline GA at birth (w) & $30.3 \pm 2.3$ & $39.3 \pm 1.1$ & $<0.001$ \\
\hline Birth weight (g) & $1598 \pm 543$ & $3272 \pm 198$ & 0.009 \\
\hline 1-min Apgar score & $5.8(4-8)$ & $8(6-10)$ & $<0.001$ \\
\hline 5-min Apgar score & $8.5(6-10)$ & $9.2(8-10)$ & $<0.001$ \\
\hline
\end{tabular}

PPROM: Premature rupture of membrane, GA: Gestational age

oxidative stress conditions such as Hydrogen peroxide $\left(\mathrm{H}_{2} \mathrm{O}_{2}\right)$, 6-hydroxydopamine and high glucose ${ }^{(23)}$.

The mean range of serum PARK-7 levels in healthy individuals differs from study to study. In a study for chronic pancreatitis and pancreatic cancer, healthy controls had a mean level of $0.6236(0.4221-2.0) \mathrm{ng} / \mathrm{mL}^{(24)}$. In two studies conducted for Parkinson's disease (PD), serum concentrations of PARK-7 were found at $18.1( \pm 12.8) \mathrm{ng} / \mathrm{mL}$ and $2.49( \pm 0.60) \mathrm{ng} / \mathrm{mL}$, and in both studies, no significant difference was observed in serum levels between PD and controls ${ }^{(25,26)}$.

PARK-7 is stained immunohistochemically in the syncytiotrophoblast, cytotrophoblasts, vascular endothelial cells, and stroma, and the immunoreactivity is found to be higher in the syncytiotrophoblast of preeclamptic placentas compared to healthy placentas ${ }^{(27)}$.

According to the aforementioned studies, PARK-7 seems to increase in diseases associated with inflammation and hypoxia induced cells such as pancreatitis pancreatic cancer, and

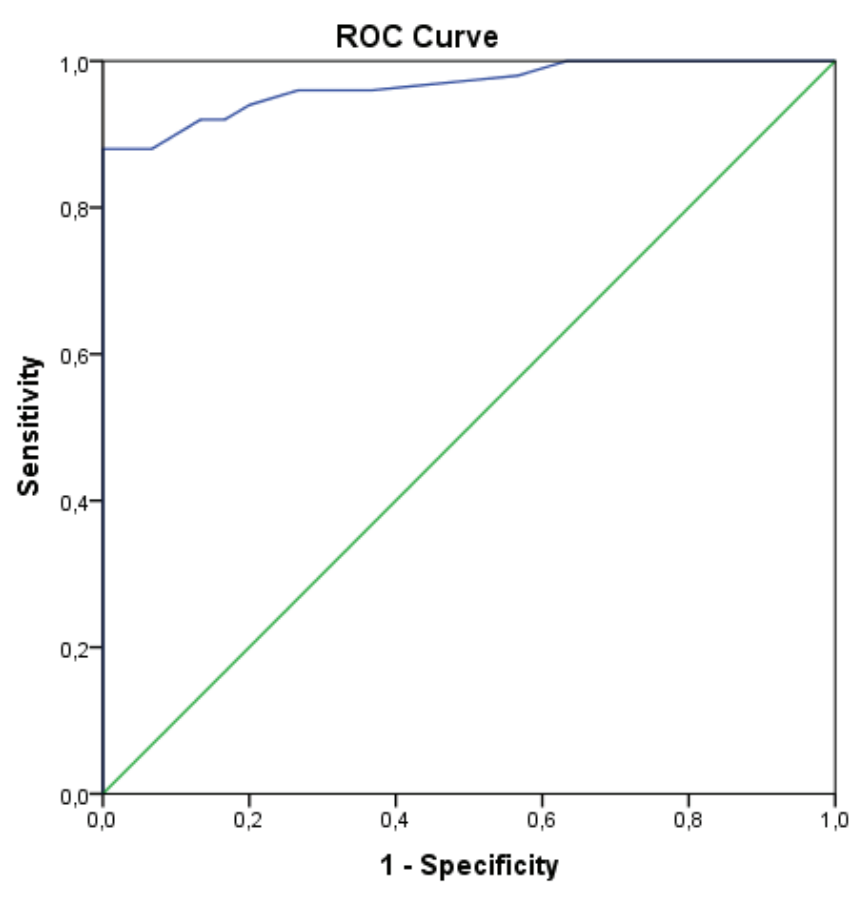

Figure 2. Receiver operating characteristic (ROC) curve of PARK 7 for prediction of PPROM

Table 3. Correlation analyses between maternal serum PARK 7 and clinical parameters

\begin{tabular}{|c|c|c|}
\hline \multicolumn{3}{|c|}{ PARK 7 n (50) } \\
\hline PPROM & $\mathrm{r}$ & p \\
\hline Age & -0.04 & 0.74 \\
\hline BMI & -0.19 & 0.18 \\
\hline GA at sampling & -0.07 & 0.59 \\
\hline GA at birth & -0.5 & 0.001 \\
\hline Birth weight & -0.49 & 0.001 \\
\hline Apgar 5 & -0.07 & 0.58 \\
\hline Apgar 10 & -0.45 & 0.001 \\
\hline WBC & 0.29 & 0.039 \\
\hline CRP & 0.57 & 0.001 \\
\hline PCT & 0.17 & 0.23 \\
\hline
\end{tabular}

r: Spearman's coefficient. p values $<0.05$ is considered statistically significant

preeclampsia, but serum level does not differ in $\mathrm{PD}$, where expression is increased in neural tissue ${ }^{(26)}$.

The main events attributed to the physiopathology of PPROM: inflammation, infection, oxidative stress and collagenolytic enzyme activation resulting impaired apoptosis of fetal membranes $^{(28)}$.

Increased mitochondrial activity and ROS production against oxidative stress induces PARK 7 , which has increased expression in severe preeclampsia in patients with defective trophoblastic invasion in the placenta ${ }^{(29,30)}$. 
On the other hand, there must be a balanced matrix metalloproteinase (MMP)/(tissue inhibitor of metallo-proteinase) TIMP system is involved in the production of collagen, which is necessary for membrane health ${ }^{(31)}$. PARK 7 down-regulation decreases the expression of MMP 2 and MMP 9 ${ }^{(32)}$. To this respect, PARK-7 overexpression is expected in PPROM in which the MMP system is over-expressive. In this study, with a cutoff value of $2.57 \mathrm{pg} / \mathrm{mL}$; PARK 7 had 92\% sensitivity. 86\% specificity, $88 \%$ positive predictive value and $83 \%$ negative predictive value $(\mathrm{p}<0.01)$ for PPROM.

Limited studies on PARK 7 were conducted in pregnancy and most of them focused on migration, cellular adhesion, and invasion in trophoblasts ${ }^{(30,32)}$. Especially, it is more expressed from syncytiotrophoblast and cytotrophoblast cells in the 1st trimester than the $3^{\text {rd }}$ trimester $^{(32)}$. In humans, fetal membranes play a role both during normal birth and in PPROM. Studies have not yet clearly defined how this balance is disturbed in PPROM, but proteases can activate MMPs with infection or inflammation of membranes thereby causing collagen catabolism and membrane rupture. PARK-7 levels were found to be positively correlated with WBC and serum CRP levels, consistent with the aforementioned hypothesis. After rupture of membranes, subclinical infection and inflammation rate increases with time, and this may increase serum PARK-7 levels ${ }^{(19)}$. In our study, we measured PARK-7 levels not more than 12 hours after diagnosing PPROM. Therefore, the effect of possible infection and inflammation on PARK-7 levels is minimized.

\section{Study Limitations}

Limitations of this study included small sample size and lack of follow-up of serum WBC, CRP and PARK-7 levels that we cannot conclude the rise of PARK-7 is limited to antenatal period.

\section{Conclusion}

To date, the relationship between plasma PARK-7 levels in healthy pregnancy and PPROM was unknown. To the best of our knowledge, this is the first study evaluating maternal serum PARK7 levels in PPROM patients. PARK 7 levels can be combined with WBC, CRP, PCT in the follow-up of PPROM. Further studies with large series are warranted to confirm these findings.

\section{Acknowledgments}

The authors would like to thank Şafak Hatırnaz Assoc. Prof. and Aytaç Yüksel, Assoc. Prof. for critical revision of the article, İsmail Dağ, MD. for helping sample collection. Trial registration number: CAEK 2019/2/13. Date of registration: 25 July 2019.

\section{Ethics}

Ethics Committee Approval: The study was approved by the Local Ethics Committee with the approval number of CAEK 2019/2/13 in accordance with the 2003 Helsinki Declaration.
Informed Consent: Inform consent was obtained.

Peer-review: Externally and internally peer-reviewed. Authorship Contributions

Concept: B.T., Design: B.T., Data Collection or Processing: U.T., Analysis or Interpretation: U.T., Literature Search: U.T., Writing: B.T.

Conflict of Interest: No conflict of interest was declared by the authors.

Financial Disclosure: The authors declared that this study received no financial support.

\section{References}

1. Manuck TA, Varner MW. Neonatal and early childhood outcomes following early vs later preterm premature rupture of membranes. Am J Obstet Gynecol 2014;211:308.el-6. doi: 10.1016/j. ajog.2014.05.030.

2. Bouvier D, Forest JC, Blanchon L, Bujold E, Pereira B, Bernard N, et al. Risk factors and outcomes of preterm premature rupture of membranes in a cohort of 6968 pregnant women prospectively recruited. J Clin Med 2019;8:1987.

3. Sae-Lin P, Wanitpongpan P. Incidence and risk factors of preterm premature rupture of membranes in singleton pregnancies at Siriraj Hospital. J Obstet Gynaecol Res 2019;45:573-7.

4. Lorthe E. Épidémiologie, facteurs de risque et pronostic de l'enfant. RPC : rupture prématurée des membranes avant terme CNGOF [Epidemiology, risk factors and child prognosis: CNGOF Preterm Premature Rupture of Membranes Guidelines]. Gynecol Obstet Fertil Senol 2018;46:1004-21. (French)

5. Mercer BM, Goldenberg RL, Meis PJ, Moawad AH, Shellhaas C, Das A, et al. The Preterm Prediction Study: prediction of preterm premature rupture of membranes through clinical findings and ancillary testing. The national institute of child health and human development maternal-fetal medicine units network. Am J Obstet Gynecol 2000;183:738-45.

6. Kacerovsky M, Musilova I, Andrys C, Drahosova M, Hornychova H, Rezac A, et al. Oligohydramnios in women with preterm prelabor rupture of membranes and adverse pregnancy and neonatal outcomes. PLoS One 2014;9:e105882. doi: 10.1371/journal. pone.0105882.

7. Bendon RW, Faye-Petersen O, Pavlova Z, Qureshi F, Mercer B, Miodovnik $\mathrm{M}$, et al. Fetal membrane histology in preterm premature rupture of membranes: comparison to controls, and between antibiotic and placebo treatment. The National Institute of Child Health and Human Development Maternal Fetal Medicine Units Network, Bethesda, MD, USA. Pediatr Dev Pathol 1999;2:552-8.

8. Seliem W, Sultan AM. Presepsin as a predictor of early onset neonatal sepsis in the umbilical cord blood of premature infants with premature rupture of membranes. Pediatr Int 2018;60:428-32.

9. Etyang AK, Omuse G, Mukaindo AM, Temmerman M. Maternal inflammatory markers for chorioamnionitis in preterm prelabour rupture of membranes: a systematic review and meta-analysis of diagnostic test accuracy studies. Syst Rev 2020;9:141.

10. Chaiworapongsa T, Erez O, Kusanovic JP, Vaisbuch E, MazakiTovi S, Gotsch F, et al. Amniotic fluid heat shock protein 70 concentration in histologic chorioamnionitis, term and preterm parturition. J Matern Fetal Neonatal Med 2008;21:449-61.

11. Le Ray I, Mace G, Sediki M, Lirussi F, Riethmuller D, Lentz N, et al. Changes in maternal blood inflammatory markers as a predictor 
of chorioamnionitis: a prospective multicenter study. Am J Reprod Immunol 2015;73:79-90.

12. Thornburg LL, Queenan R, Brandt-Griffith B, Pressman EK. Procalcitonin for prediction of chorioamnionitis in preterm premature rupture of membranes. J Matern Fetal Neonatal Med 2016;29:2056-61.

13. Oludag T, Gode F, Caglayan E, Saatli B, Okyay RE, Altunyurt S Value of maternal procalcitonin levels for predicting subclinical intra-amniotic infection in preterm premature rupture of membranes. J Obstet Gynaecol Res 2014;40:954-60.

14. Torbé A. Maternal plasma procalcitonin concentrations in pregnancy complicated by preterm premature rupture of membranes. Mediators Inflamm 2007;2007:35782.

15. Bonifati V, Rizzu P, van Baren MJ, Schaap O, Breedveld GJ, Krieger $\mathrm{E}$, et al. Mutations in the DJ-1 gene associated with autosomal recessive early-onset parkinsonism. Science 2003;299:256-9.

16. Cao J, Lou S, Ying M, Yang B. DJ-1 as a human oncogene and potential therapeutic target. Biochem Pharmacol 2015;93:241-50.

17. Nagakubo D, Taira T, Kitaura H, Ikeda M, Tamai K, Iguchi-Ariga $\mathrm{SM}$, et al. DJ-1, a novel oncogene which transforms mouse NIH3T3 cells in cooperation with ras. Biochem Biophys Res Commun 1997;231:509-13.

18. Zhong N, Xu J. Synergistic activation of the human MnSOD promoter by DJ-1 and PGC-1alpha: regulation by SUMOylation and oxidation. Hum Mol Genet 2008;17:3357-67.

19. Amatullah H, Shan Y, Beauchamp BL, Gali PL, Gupta S, MaronGutierrez T, et al. DJ-1/PARK7 impairs bacterial clearance in sepsis. Am J Respir Crit Care Med 2017;195:889-905.

20. Zhang L, Wang J, Wang J, Yang B, He Q, Weng Q. Role of DJ-1 in Immune and Inflammatory Diseases. Front Immunol 2020;11:994.

21. Czikk MJ, McCarthy FP, Murphy KE. Chorioamnionitis: from pathogenesis to treatment. Clin Microbiol Infect 2011;17:1304-11.

22. Kahle PJ, Waak J, Gasser T. DJ-1 and prevention of oxidative stress in Parkinson's disease and other age-related disorders. Free Radic Biol Med 2009;47:1354-61.
23. Shinbo Y, Niki T, Taira T, Ooe H, Takahashi-Niki K, Maita C, et al. Proper SUMO-1 conjugation is essential to DJ-1 to exert its full activities. Cell Death Differ 2006;13:96-108.

24. He XY, Liu BY, Yao WY, Zhao XJ, Zheng Z, Li JF, et al. Serum DJ-1 as a diagnostic marker and prognostic factor for pancreatic cancer. J Dig Dis 2011;12:131-7.

25. An C, Pu X, Xiao W, Zhang H. Expression of the DJ-1 protein in the serum of Chinese patients with Parkinson's disease. Neurosci Lett 2018;665:236-9.

26. Zhao ZH, Chen ZT, Zhou RL, Zhang X, Ye QY, Wang YZ. Increased DJ-1 and $\alpha$-Synuclein in Plasma Neural-Derived Exosomes as Potential Markers for Parkinson's Disease. Front Aging Neurosci 2019;10:438.

27. Kwon HS, Hwang HS, Sohn IS, Park SH. Expression of DJ-1 proteins in placentas from women with severe preeclampsia. Eur J Obstet Gynecol Reprod Biol 2013;168:40-4.

28. Menon R, Richardson LS. Preterm prelabor rupture of the membranes: a disease of the fetal membranes. Semin Perinatol 2017;41:409-19.

29. Aouache R, Biquard L, Vaiman D, Miralles F. Oxidative stress in preeclampsia and placental diseases. Int J Mol Sci 2018;19:1496.

30. Yang T, Yan J, Han Q, Zhang Q, Liao Q. Expression and significance of Parkinson disease protein 7 in placental, serum and umbilical cord blood in preeclampsia. Ginekol Pol. 2020;91:764-8.

31. Ulug U, Goldman S, Ben-Shlomo I, ShalevE. Matrix metalloproteinase (MMP)-2 and MMP-9 and their inhibitor, TIMP-1, in human term decidua and fetal membranes: the effect of prostaglandin $\mathrm{F}$ (2alpha) and indomethacin. Mol Hum Reprod 2001;7:1187-93.

32. Kwon HS, Park JH, Hwang HS, Sohn IS, Kim YH, Cho S. Effect of DJ-1 Downregulation on the Functions of the First Trimester Extravillous Trophoblasts. Reprod Sci 2018;25:1436-45. 